THE INTERNATIONAL JOURNAL FOR THE PSYCHOLOGY OF RELIGION, 17(3), 209-232

Copyright @ 2007, Lawrence Erlbaum Associates, Inc.

\title{
RESEARCH
}

\section{Religiousness and Depressive Symptoms in Five Ethnic Adolescent Groups}

\author{
Thao N. Le \\ Colorado State University \\ National Council on Crime and Delinquency \\ William Tov \\ University of Illinois at Urbana-Champaign \\ Julie Taylor \\ Colorado State University
}

\begin{abstract}
This study examined the relation between religiousness and depressive symptoms in African American, Asian American, European American, Hispanic American, and Native American adolescents $(N=13,317)$ in the United States with selfesteem and school attachment as potential mediators in this link. The data were taken from a nationally represented sample of adolescents in Grades 7 through 12, from the National Longitudinal Study of Adolescent Health (Add Health). Structural equation analyses with measurement and structural invariance across the five ethnic groups and gender supported the model that religiousness, as a composite of internal and external religiousness items, negatively predicted depressive symptoms 1 year later controlling for baseline depressive symptoms. Self-esteem and school attachment partially mediated this link but only for European American and African American adolescents.
\end{abstract}

Correspondence should be sent to Thao Le, 119G Gifford, Colorado State University, Fort Collins, CO 80523.E-mail: tle@ cahs.colostate.edu 
Over the past decade, there has been an increasing interest in the link between religious involvement and mental health. Early research in this area produced a variety of disparate findings such that arguments could be made for either the beneficial or detrimental effects of religion on well-being. However, recent reviews of the literature are now converging on the consensus that religiousness maintains a modest but positive association with psychological well-being (Hackney \& Sanders, 2003; Koenig, 2001; T. B. Smith, McCullough, \& Poll, 2003). Such a convergence is encouraging but also raises a number of questions regarding the generalizability of such findings as well as the processes and mechanisms underlying the relation between religion and mental health. For instance, an important limitation of the research leading up to these reviews concerns the relative homogeneity of the samples that have been studied. To the extent that the majority of participants have tended to be of college-age or older, as well as European or European American, it remains to be seen whether religious involvement is associated with well-being among other, less studied groups.

A particularly important extension of the work on religion and well-being is the research on religious involvement and adolescent mental health. Adolescence is a critical period of physical, mental, and social development. Teenagers often confront a number of emotional and psychological challenges as they deal with changes in social roles and expectations. Estimates of the lifetime prevalence of major depressive disorder in adolescents range from $15 \%$ to 20\% (Birmaher et al., 1996). Yet of the 147 studies included in T. B. Smith et al.'s (2003) comprehensive meta-analysis of the research on religiousness and depression, only $7 \%$ involved adolescent participants. Using various operationalizations, the existing research suggests that greater religious involvement is associated with lower depression in adolescents. These different measures of involvement include frequency of attendance at religious services (Schapman \& Inderbitzen-Nolan, 2002; Wright, Frost, \& Wisecarver, 1993), frequency of prayer (Miller \& Gur, 2002; Schapman \& Inderbitzen-Nolan, 2002), participation in religious youth groups (Miller \& Gur, 2002; Schapman \& InderbitzenNolan, 2002), meaningfulness or importance of religion to the self (Peltzer, 2005; Schapman \& Inderbitzen-Nolan, 2002; Wright et al., 1993), and positive interpersonal experiences with fellow members of one's religious group (Pearce, Little, \& Perez, 2003). However, studies involving older adolescents or college freshmen have yielded equivocal results. Peltzer (2005) found no clear association between depression and either church attendance or frequency of prayer in South African high school and college students. Similarly, attendance and self-rated religiousness did not correlate significantly with depression among Canadian freshmen (Hunsberger, Pratt, \& Pancer, 2001). These patterns might be related to declines in religious activity as adolescents grow older (Benson, 
Donahue, \& Erickson, 1989), although cultural factors such as values might also play a role.

Although the research is slowly cumulating, several gaps remain in our understanding of religion and adolescent mental health. First, studies of religious involvement and adolescent depression tend to be limited by cross-sectional designs (Peltzer, 2005; Schapman \& Inderbitzen-Nolan, 2002; Wright et al., 1993). Although religiousness may reduce the likelihood of developing depression, researchers are often unable to rule out the possibility that depression results in decreased religious participation-a phenomenon that would also produce negative correlations between religiousness and depression. Consequently, a number of researchers have called for more longitudinal studies to shed light on the causal mechanisms relating religion and mental health (Baetz, Griffin, Bowen, Koenig, \& Marcoux, 2004; Eliassen, Taylor, \& Lloyd, 2005; Greening \& Stoppelbein, 2002; Pearce et al., 2003; Wright et al., 1993). In a longitudinal design, preexisting levels of depression are statistically controlled to determine whether religiousness predicts increases or decreases in depression at a later point in time. Thus, stronger inferences can be made regarding the direction of influence between religious involvement and depression. Second, the research on religious involvement and depression in adolescence has tended to proceed separately from other investigations of adolescent well-being such as religiousness and self-esteem, or self-esteem and depression. There have been few attempts to integrate these various approaches to illuminate the processes that mediate the relation between religious involvement and depression. The study presented here seeks to address these gaps in the literature by employing a large, longitudinal sample of adolescents and using statistical modeling to explore the links among religiousness, self-esteem, school attachment, and depression. Moreover, the ability of the model to adequately account for the relation between religious involvement and depression is evaluated separately for five ethnic adolescent samples.

\section{SELF-ESTEEM AND SCHOOL ATTACHMENT AS POTENTIAL MEDIATORS}

\section{Religious Involvement and Self-Esteem}

According to the cultural value hypothesis, to the extent that being religious is a valued cultural ideal, then religious involvement should lead to increases in self-esteem, because one is engaging in culturally valued behavior. C. B. Smith, Weigert, and Thomas (1979) found some support for this hypothesis in their investigation of religiosity among Catholic adolescents in five cultures. Because 
these adolescents were attending Catholic school, they were in a community in which religious involvement was clearly valued. Indeed, religious beliefs and the frequency of religious practice were both associated with greater self-esteem in all cultures except Mexico and Puerto Rico. Similarly, religion occupies a central role in the African American community, and religious participation is positively associated with self-esteem in African American adolescents (Ball, Armistead, \& Austin, 2003; Mizell, 1999).

A similar hypothesis was invoked by Abbotts, Williams, Sweeting, and West (2004) to explain why church attendance was associated with higher self-esteem among Scottish children in Catholic school but lower self-esteem among their peers at a predominantly Protestant school. According to Abbotts et al., whereas religious practice is normative for Catholic students, it is looked down upon by Protestant students. However, rather than self-esteem arising from meeting a valued cultural ideal, the authors proposed that religiousness enabled Catholic children to fit in with their peers but evoked teasing and bullying for Protestant children. Indeed, religious practice was associated with increased victimization among the Protestant children (Abbotts et al., 2004).

Other studies have yielded mixed support for the link between religious involvement and self-esteem. Bagley and Mallick (1997) observed a positive association between attendance at religious service and self-esteem in Canadian adolescents, regardless of whether they attended a Catholic school or a public school. In contrast, three other studies failed to find any relation between religious participation and self-esteem (Bahr \& Martin, 1983; Hunsberger et al., 2001; Markstrom, 1999). Given that the findings have been inconsistent, more research on the relation between religious involvement and self-esteem is needed. Therefore, we consider self-esteem as a factor in our investigation of religious involvement and depression.

If religious involvement is associated with self-esteem, then the question arises as to whether self-esteem itself mediates the relation between religious involvement and depression. Self-esteem and depression are often correlated negatively (e.g., Cheng \& Furnham, 2003; Portes \& Zady, 2002), and adolescents who reported suffering from a past episode of severe depression tended to have lower levels of self-esteem as well as greater depression in the present than teens who did not report experiencing such an episode (Roberts \& Gamble, 2001). Robertson and Simons (1989) also observed a strong concurrent association between self-esteem and depression, although self-esteem failed to predict depression 1 year later. However, more than half of their sample consisted of youth who were admitted into drug treatment programs. In our study, we examine whether the results of Robertson and Simons generalize to a larger, nationally representative sample. 


\section{Religious Involvement and School Attachment}

School attachment refers to a sense of belonging at school and may be an important factor in adolescent well-being for a number of reasons. First, students who have low school attachment tend to be less involved at school; exhibit lower academic performance; and are more likely to report feeling lonely, alienated, and depressed (Anderman, 2002; Mouton, Hawkins, McPherson, \& Copley, 1996). In contrast, attached students tend to perform well academically and have greater educational aspirations, characteristics that have been associated with higher self-esteem even after controlling for religious involvement (Bahr \& Martin, 1983; Donahue \& Benson, 1995). Second, school attachment seems to imply greater social support. Students who do not feel attached to school tend to perceive a lack of support and encouragement from fellow students, teachers, and other school personnel (Mouton et al., 1996) and score higher on measures of social rejection (Anderman, 2002).

The association between religious involvement and school attachment has been understudied, even though there are theoretical explanations linking the two together. For example, Markstrom (1999) suggested that religious involvement might provide adolescents with opportunities to develop skills such as self-improvement that are also useful in the academic context. She found that church attendance, involvement in youth groups, and Bible study were associated with higher school self-esteem. Church attendance and private prayer were also associated with more positive attitudes toward school among 11year-old children in England (Francis, 1992). Another way in which religious involvement might foster school attachment is through the development of social skills that facilitate better integration and attachment at school. Pearce et al. (2003) stressed the importance of the social aspect of religious participation. Whereas positive interpersonal experiences with one's religious group were associated with less depression, negative interpersonal experiences were associated with greater depression. This result suggests the possibility that religion affects depression indirectly, through the development of social skills and social support, which in turn help to buffer against depression in times of stress. Of course, school attachment itself represents only one form of social support. Nevertheless, given the central role of schooling in the psychosocial development of adolescents, our study examines whether religious involvement affects depression directly or indirectly through school attachment. If direct effects are found, this would suggest that the process by which religiousness influences adolescent depression is not limited to the domain of schooling but may extend beyond it to other important factors such as the family or the larger community. 


\section{ETHNIC AND GENDER DIFFERENCES}

Another aim of our research is to expand on analyses of ethnic and gender differences in the relation between religious involvement and depression. These analyses are important given that such differences have been reported in the existing literature on adolescent well-being. Female adolescents often report greater depression (Eliassen et al., 2005; Pearce et al., 2003; Portes \& Zady, 2002; Roberts \& Gamble, 2001; Wright et al., 1993) and religiosity (Donahue \& Benson, 1995; Eliassen et al., 2005; Wright et al., 1993) as well as lower self-esteem (Roberts \& Gamble, 2001) than their male peers.

With regard to ethnic differences, African American adolescents tend to report higher levels of both depression (Eliassen et al., 2005; Greening \& Stoppelbein, 2002) and religious involvement (Donahue \& Benson, 1995; Eliassen et al., 2005; Markstrom, 1999) than European American adolescents. Few studies have examined ethnic differences in the relation between religious involvement and depression. Pearce et al. (2003) found that the association between interpersonal religious experiences and depression was not moderated by whether adolescents were African American or European American. Eliassen et al. examined religious coping and depression in adolescents but found no difference among European American, African American, and Hispanic American samples. To date, no studies that we are aware of have examined the complex interrelations among religious involvement, self-esteem, school attachment, and depression in Asian American and Native American groups. Such studies are important because rates of depression may be higher among groups such as Asian and Pacific Islanders (Office of the Surgeon General, 2001). Portes and Zady (2002) found that Southeast Asian immigrant adolescents reported lower self-esteem than Spanish-speaking adolescents. Thus, our modeling of religious involvement and depression not only serves to integrate existing strains of research but also examines the generalizability of the model across gender and five ethnic adolescent groups in the U.S.

\section{HYPOTHESES}

Based on these previous findings and conceptual arguments, we predict modest negative associations between religiousness and depression for both male and female adolescents and across the five different ethnicities (African American, Asian American, European American, Hispanic American, and Native American). We also hypothesize that this relation would be mediated by self-esteem and school attachment. Specifically, religiousness would be positively related to self-esteem, and self-esteem would be negatively related to depression. Like- 
wise, religiousness would be positively related to school attachment, and school attachment would be negatively related to depression.

\section{METHOD}

\section{Sample}

The National Longitudinal Study of Adolescent Health ${ }^{1}$ (Add Health) consists of a nationally representative sample of adolescents in Grades 7 through 12 . It was initially conducted during the 1994-95 school year beginning with a stratified, random sample of high schools in the United States. A self-weighted sample and several special samples (e.g., educated African Americans) were also selected for in-home interviews that lasted for $90 \mathrm{~min}$. The in-home interview consisted of an in-depth questionnaire that was administered by laptops; audio computer-assisted self-interview technology was used for sensitive topics in the questionnaire. About 20,000 Wave 1 in-home interviews were completed in 1995 with follow-ups in 1996 (Wave 2) that included about 15,000 respondents (88\% of those eligible).

\section{Measures}

Demographics included age, gender, and ethnicity, which were all self-reported. For gender, male was coded as 1 , and female was coded as 2. Ethnicity included youth self-identification as African American, Asian American, European American, Hispanic American, or Native American.

Religiousness measures included religious affiliation and religiousness as a composite of internal and external religiousness. For religious affiliation, participants responded to the question "What is your religion?" and selected from a set of religious categories (e.g., Atheist, Buddhist, Catholic, Jew, Protestant, etc.). We also coded this variable into 0 for no affiliation and 1 for any affiliation.

Internal religiousness was measured by two items. One item asked respondents, "How important is religion to you?" Participants responded on a scale of

\footnotetext{
${ }^{1}$ This research uses data from Add Health, a program project designed by J. Richard Udry, Peter S. Bearman, and Kathleen Mullan Harris, and funded by a grant P01-HD31921 from the National Institute of Child Health and Human Development, with cooperative funding from 17 other agencies. Special acknowledgment is due Ronald R. Rindfuss and Barbara Entwisle for assistance in the original design. Individuals interested in obtaining data files from Add Health should contact Add Health, Carolina Population Center, 123 West Franklin Street, Chapel Hill, NC 27516-2524; addhealth@unc.edu
} 
1 (very important) to 4 (not important at all). The second item asked respondents how often they pray with responses ranging from 1 (at least once a day) to 5 (never). The items were reverse coded such that a higher score indicated greater internal religiousness. External religiousness was also measured by two items. The first item asked, "In the last 12 months, how often did you attend religious services?" Responses ranged from 1 (once a week or more) to 4 (never). The second item asked about the frequency of participation in youth activities in churches, synagogues, and other places of worship with special activities for teenagers such as Bible classes, choir, and so on. Responses ranged from 1 (once a week or more) to 4 (never). The items were reverse coded such that a higher score indicated greater external religiousness. Internal and external religiousness were significantly highly positively correlated with each other $(r=.78$, $p<.001$ ), suggesting that these two dimensions were essentially reflecting one construct. Hence, we combined these four items into one scale.

Depression was measured by a 19-item scale modified from the slightly longer Center for Epidemiological Studies Depression Scale (Radloff, 1977) at Wave 1 (1995) and Wave 2 (1996). Each item asked the respondent, "How often was each of the following things true during the past week?" Items included statements such as "You felt sad" and "You felt lonely." This scale was treated as a continuous measure of depression, with higher scores denoting greater depression. On the full Center for Epidemiological Studies Depression Scale, ranging from 0 to 60,16 is usually the cutoff point in terms of threshold for clinical depression (Radloff, 1977). This scale is considered a widespread and valid measure of depression. School attachment was measured by five items that asked respondents how much they agree or disagree with such statements as "You feel close to people at your school," "You are happy to be at your school," and "You feel safe in your school." Participants responded to these items on a 5-point scale from 1 (strongly agree) to 5 (strongly disagree). The items were reverse coded such that a higher score indicated greater school attachment.

Self-esteem was measured by the Rosenberg Self-Esteem Inventory (Rosenberg, 1965). Participants responded to these items on a 5-point scale ranging from 1 (strongly agree) to 5 (strongly disagree). Half of the items are in the reverse direction to reduce the possibility of acquiescence.

\section{Analysis Plan}

Structural equation model (SEM) using Mplus 3.1 (Muthén \& Muthén, 2003) was used to assess measurement and structural invariance, and the relations among the variables of interest. For each of the five scales, a latent variable was created using three item parcels as recommended by Kishton and Widaman (1994). Thus, five latent variables of three indicators each were used for SEM measurement and structural models. 


\section{RESULTS}

\section{Descriptive Statistics}

Correlations among the five manifest scales are shown in the Appendix. Means and standard deviations for the five ethnic groups and gender are presented in Table 1. Although measurement invariance has not yet been established for these constructs, and definitive mean comparisons should first require legitimate factorial invariance, there were some noteworthy differences at the manifest level. Specifically, depression at both Waves 1 and 2 were similar for all ethnic groups with the exception of European Americans, in which the depression levels were significantly lower. African Americans had the highest levels of self-esteem, followed by European Americans. On the other hand, African Americans had significantly lower levels of school attachment than the other groups, with the exception of Native Americans. African Americans also tended to be the most religious, followed by Hispanic, European, and Native Americans, whereas Asian Americans were statistically indistinguishable from Hispanic and European Americans.

Gender differences were also observed, with female adolescents reporting higher levels of depression at both Waves 1 and 2, as well as greater religiousness. However, male adolescents reported higher self-esteem. These findings are consistent with past research. Male and female participants did not differ on school attachment.

\section{Factorial (Measurement) and Structural Invariance}

Ethnic groups. Table 2 presents the fit index values for various levels of measurement factorial invariance (i.e., whether the factor loadings, error variances, variances, etc., are similar) for the five ethnic groups. With the exception of the baseline to weak factorial invariance model, the fit decreased at each level of parameter restriction. Weak factorial invariance (i.e., factor loadings were the same across the groups) was the best fitting model across these groups, as the $\chi^{2} / d f$ ratio (8.32) and the root mean square error of approximation (RMSEA; .053) were lower than those of the other models, and the weak factorial invariance Tucker-Lewis Index (TLI; .951) was higher than that of the other factorial invariance models. Thus, direct relations among the path coefficients in the subsequent structural models as well as direct mean comparisons on both the latent and manifest levels (Table 1) could be legitimately performed.

Given the aforementioned results of measurement invariance, structural invariance was then examined in which three structural models (i.e., no mediation model, partial mediation model, full mediation model), all adhering to weak factorial measurement invariance constraints, were compared. That is, for all factors, 
TABLE 1

Means, Standard Deviations, and Internal Consistency Reliability for Ethnic Groups and Gender on Manifest Scales

\begin{tabular}{|c|c|c|c|c|c|}
\hline Group & $\begin{array}{c}\text { Depression } \\
\text { Wave } 1\end{array}$ & Religion & $\begin{array}{c}\text { Self- } \\
\text { Esteem }\end{array}$ & $\begin{array}{c}\text { School } \\
\text { Attachment }\end{array}$ & $\begin{array}{c}\text { Depression } \\
\text { Wave } 2\end{array}$ \\
\hline \multicolumn{6}{|c|}{ Ethnic group } \\
\hline \multicolumn{6}{|c|}{ Hispanic American $_{a}$} \\
\hline$M$ & $12.14^{\mathrm{a}}$ & $10.98^{\mathrm{a}}$ & $28.14^{\mathrm{a}}$ & $3.73^{\mathrm{a}}$ & $12.64^{\mathrm{a}}$ \\
\hline$S D$ & 0.24 & 0.16 & 0.14 & 0.02 & 0.25 \\
\hline$\alpha$ & 0.86 & 0.86 & 0.85 & 0.75 & 0.86 \\
\hline \multicolumn{6}{|c|}{ European American $_{b}$} \\
\hline$M$ & $10.29^{b}$ & $10.36^{\mathrm{b}}$ & $28.57^{\mathrm{b}}$ & $3.74^{\mathrm{a}}$ & $10.09^{\mathrm{b}}$ \\
\hline$S D$ & 0.11 & 0.08 & 0.06 & 0.01 & 0.11 \\
\hline$\alpha$ & 0.87 & 0.91 & 0.86 & 0.78 & 0.88 \\
\hline \multicolumn{6}{|c|}{ African American $_{c}$} \\
\hline$M$ & $12.34^{\mathrm{a}}$ & $11.68^{\mathrm{c}}$ & $29.41^{\mathrm{c}}$ & $3.65^{\mathrm{b}}$ & $12.06^{\mathrm{a}}$ \\
\hline$S D$ & 0.21 & 0.15 & 0.10 & 0.02 & 0.20 \\
\hline$\alpha$ & 0.85 & 0.90 & 0.82 & 0.74 & 0.85 \\
\hline \multicolumn{6}{|c|}{ Asian American ${ }_{d}$} \\
\hline$M$ & $12.49^{\mathrm{a}}$ & $10.97^{\mathrm{a}, \mathrm{b}}$ & $27.70^{\mathrm{a}}$ & $3.78^{\mathrm{a}}$ & $12.34^{\mathrm{a}}$ \\
\hline$S D$ & 0.36 & 0.31 & 0.21 & 0.03 & 0.37 \\
\hline$\alpha$ & 0.86 & 0.91 & 0.86 & 0.73 & 0.87 \\
\hline \multicolumn{6}{|c|}{ Native American $_{e}$} \\
\hline$M$ & $13.04^{\mathrm{a}}$ & $9.51^{\mathrm{d}}$ & $27.97^{\mathrm{a}}$ & $3.46^{\mathrm{c}}$ & $12.26^{\mathrm{a}}$ \\
\hline$S D$ & 0.53 & 0.34 & 0.26 & 0.05 & 0.55 \\
\hline$\alpha$ & 0.87 & 0.91 & 0.83 & 0.77 & 0.89 \\
\hline \multicolumn{6}{|l|}{ Gender } \\
\hline \multicolumn{6}{|c|}{ Female $_{f}$} \\
\hline$M$ & $11.82^{\mathrm{a}}$ & $10.75^{\mathrm{a}}$ & $27.92^{\mathrm{a}}$ & $3.70^{\mathrm{a}}$ & $11.73^{\mathrm{a}}$ \\
\hline$S D$ & 0.19 & 0.10 & 0.09 & 0.02 & 0.16 \\
\hline$\alpha$ & 0.88 & 0.91 & 0.86 & 0.77 & 0.88 \\
\hline \multicolumn{6}{|l|}{ Male $_{\mathrm{g}}$} \\
\hline$M$ & $9.97^{b}$ & $10.17^{b}$ & $28.75^{\mathrm{b}}$ & $3.73^{\mathrm{a}}$ & $9.84^{\mathrm{b}}$ \\
\hline$S D$ & 0.15 & 0.09 & 0.08 & 0.02 & 0.17 \\
\hline$\alpha$ & 0.84 & 0.91 & 0.83 & 0.76 & 0.85 \\
\hline
\end{tabular}

Note. Gender was coded as $1=$ male, $2=$ female. For Ethnic Groups, means within a column with the same superscript are not significantly different, $p<.05$, Scheffé. For Gender, means within each column with the same superscript are not significantly different, $p<.05$, independent samples $t$ test.

${ }^{\mathrm{a}} n=2,033 .{ }^{\mathrm{b}} n=6,929 .{ }^{\mathrm{c}} n=2,706 .{ }^{\mathrm{d}} n=981 .{ }^{\mathrm{e}} n=459 .{ }^{\mathrm{f}} n=6,813 .{ }^{\mathrm{g}} n=6,504$. 
TABLE 2

Fit Indices of Factorial Invariance Measurement Models for Ethnicity and Gender

\begin{tabular}{|c|c|c|c|c|c|c|c|c|c|c|}
\hline Model (Group Invariance) & $\chi^{2}$ & $d f$ & $p$ & $\chi^{2}: d f$ & $\Delta \chi^{2}$ & $\Delta d f$ & $\Delta \chi^{2}: \Delta d f$ & RMSEA & $T L I$ & CFI \\
\hline \multicolumn{11}{|l|}{ Ethnicity } \\
\hline \multicolumn{11}{|l|}{ Measurement models } \\
\hline 00. Baseline (configural invariance) & 3501.56 & 400 & $<.01$ & 8.75 & & & & .054 & .948 & .961 \\
\hline $\begin{array}{l}\text { 01. Model } 00+\ldots \text { invariant } \\
\text { (weak factorial invariance) }\end{array}$ & 3661.44 & 440 & $<.01$ & 8.32 & 159.88 & 40 & 4.00 & .053 & .951 & .959 \\
\hline $\begin{array}{l}\text { 02. Model } 01+\text { invariant } \\
\text { (strong factorial invariance) }\end{array}$ & 4499.66 & 480 & $<.01$ & 9.37 & 838.22 & 40 & 20.96 & .056 & .944 & .949 \\
\hline $\begin{array}{l}\text { 03. Model } 02+{ }_{-} \text {invariant } \\
\text { (strict factorial invariance) }\end{array}$ & 5908.95 & 540 & $<.01$ & 10.94 & 1409.29 & 60 & 23.49 & .061 & .934 & .932 \\
\hline \multicolumn{11}{|l|}{ Structural models } \\
\hline 01A. No mediation & 10136.18 & 465 & $<.01$ & 21.80 & & & & .089 & .862 & .877 \\
\hline 01B. Partial mediation & 3965.49 & 445 & $<.01$ & 8.91 & & & & .055 & .947 & .955 \\
\hline 01C. Full mediation & 6663.47 & 455 & $<.01$ & 14.64 & & & & .072 & .909 & .921 \\
\hline \multicolumn{11}{|l|}{ Gender } \\
\hline \multicolumn{11}{|l|}{ Measurement models } \\
\hline 00. Baseline (configural invariance) & 3045.20 & 160 & $<.01$ & 19.03 & & & & .052 & .951 & .963 \\
\hline $\begin{array}{l}\text { 01. Model } 00+_{-} \text {invariant } \\
\text { (weak factorial invariance) }\end{array}$ & 3104.06 & 170 & $<.01$ & 18.26 & 58.86 & 10 & 3.59 & .051 & .953 & .962 \\
\hline $\begin{array}{l}\text { 02. Model } 01+\text { invariant } \\
\text { (strong factorial invariance) }\end{array}$ & 3472.93 & 180 & $<.01$ & 19.29 & 368.87 & 10 & 4.33 & .053 & .950 & .957 \\
\hline $\begin{array}{l}\text { 03. Model } 02+\ldots \text { invariant } \\
\text { (strict factorial invariance) }\end{array}$ & 3755.81 & 195 & $<.01$ & 19.26 & 282.88 & 15 & 22.65 & .053 & .950 & .954 \\
\hline \multicolumn{11}{|l|}{ Structural models } \\
\hline 01A. No mediation & 9306.59 & 180 & $<.01$ & 51.70 & & & & .088 & .862 & .882 \\
\hline 01B. Partial mediation & 3396.53 & 172 & $<.01$ & 19.75 & & & & .053 & .949 & .958 \\
\hline 01C. Full mediation & 6166.80 & 176 & $<.01$ & 35.04 & & & & .072 & .908 & .923 \\
\hline
\end{tabular}

$\underset{\omega}{0} \quad$ Note. RMSEA $=$ root mean square error of approximation; TLI $=$ Tucker-Lewis Index; CFI = comparative fit index. 
each factor indicator (parcel) loading was constrained to be equal across the five ethnic groups. In assessing for structural invariance, the paths were constrained to be equal across the five groups. In all models, religiousness and depression at Wave 1 were allowed to correlate. In the first structural model, Model 01A, religiousness, depression, self-esteem, and school attachment at Wave 1 were all specified as separate predictors of Wave 2 depression, without testing for mediation. In Model 01B, we retained the direct paths from religiousness and depression at Wave 1 to depression at Wave 2 but also tested for partial mediation of religiousness and depression through self-esteem and school attachment. Finally, Model 01C tested for full mediation through self-esteem and school attachment by constraining to zero the direct paths from religiousness and depression at Wave 1 to depression at Wave 2. The fit index values for the three structural models are presented in Table 2. The results indicated that the partial mediation model, Model 01B, was the most suitable as it had the lowest $\chi^{2} / d f$ ratio (8.91) as well as the lowest RMSEA (.055), and highest comparative fit index (CFI) and TLI index values, .955 and .947, respectively. The estimated path coefficients for all three structural models are shown in Table 3. We focus our discussion on the best fitting model (Model 01B).

For all ethnic groups in Model 01B (Table 3), depression in Wave 1 exerted a significantly strong direct effect on Wave 2 depression. Hispanic youth had the highest standardized estimate, with each unit standard deviation increase in Wave 1 depression resulting in a .69 standard deviation increase in Wave 2 depression. Although Native American youth had the lowest standardized estimate, there was still a .53 increase in Wave 2 depression per unit increase in Wave 1 depression. Wave 1 depression was a significant predictor of school attachment and self-esteem for all groups. Although religiousness was positively associated with self-esteem for all groups except Native Americans, the indirect effect of religiousness on Wave 2 depression was only observed for European and African American adolescents. For European Americans, increasing religiousness by 1 standard deviation decreases Wave 2 depression directly by .03 standard deviations and indirectly through self-esteem by $.05 \times .03=.002$ standard deviations. As such, religiousness seems to only have a modest protective effect on depression for European Americans. For African Americans, religiousness had a small protective indirect effect on depression $(.13 \times .06=.008)$ that was cancelled out by a positive direct association with depression (.08). Although school attachment was positively associated with religiousness among Hispanic, European, and African Americans, it did not predict Wave 2 depression in these groups. Among Native Americans, religiousness was not positively associated with school attachment, although the latter was negatively associated with Wave 2 depression. Thus, school attachment does not appear to mediate the relation between religiousness and depression. In general, religiousness 
TABLE 3

Standardized Estimated Path Coefficients (and $t$ Values) of Structural Models for Predicting Wave 2 Depression from Wave 1 Depression, Religiousness, Self-Esteem, and School Attachment for Ethnic Groups

\begin{tabular}{|c|c|c|c|c|c|c|c|c|}
\hline \multirow[b]{2}{*}{ Ethnic Group } & \multicolumn{2}{|c|}{$\begin{array}{c}\text { Criterion }=\text { School } \\
\text { Attachment Predictors }\end{array}$} & \multicolumn{2}{|c|}{$\begin{array}{c}\text { Criterion }= \\
\text { Self-Esteem Predictors }\end{array}$} & \multicolumn{4}{|c|}{ Criterion $=$ Depression Wave 2 Predictors } \\
\hline & $\begin{array}{l}\text { Depression } \\
\text { Wave } 1\end{array}$ & Religiousness & $\begin{array}{c}\text { Depression } \\
\text { Wave } 1\end{array}$ & Religiousness & $\begin{array}{l}\text { Depression } \\
\text { Wave } 1\end{array}$ & Religiousness & $\begin{array}{c}\text { School } \\
\text { Attachment }\end{array}$ & $\begin{array}{c}\text { Self- } \\
\text { Esteem }\end{array}$ \\
\hline \multicolumn{9}{|c|}{ Model 01A: No mediation through self-esteem and school attachment } \\
\hline Hispanic American & & & & & $\begin{array}{r}.64^{*} \\
(22.26)\end{array}$ & $\begin{array}{c}.00 \\
(-.12)\end{array}$ & $\begin{array}{c}-.04 \\
(-1.87)\end{array}$ & $\begin{array}{r}-.07^{*} \\
(-3.38)\end{array}$ \\
\hline European American & & & & & $\begin{array}{r}.62^{*} \\
(29.14)\end{array}$ & $\begin{array}{c}-.02 \\
(-1.86)\end{array}$ & $\begin{array}{c}-.06^{*} \\
(-5.18)\end{array}$ & $\begin{array}{r}-.11^{*} \\
(-9.07)\end{array}$ \\
\hline African American & & & & & $\begin{array}{r}.59^{*} \\
(22.58)\end{array}$ & $\begin{array}{r}.10^{*} \\
(4.07)\end{array}$ & $\begin{array}{c}-.05^{*} \\
(-2.39)\end{array}$ & $\begin{array}{r}-.12^{*} \\
(-5.94)\end{array}$ \\
\hline Asian American & & & & & $\begin{array}{r}.64^{*} \\
(17.95)\end{array}$ & $\begin{array}{l}-.01 \\
(-.14)\end{array}$ & $\begin{array}{c}-.04 \\
(-1.24)\end{array}$ & $\begin{array}{r}-.11^{*} \\
(-3.69)\end{array}$ \\
\hline Native American & & & & & $\begin{array}{r}.44^{*} \\
(10.96)\end{array}$ & $\begin{array}{r}.20^{*} \\
(3.81)\end{array}$ & $\begin{array}{r}-.15^{*} \\
(-3.19)\end{array}$ & $\begin{array}{r}-.08^{*} \\
(-1.73)\end{array}$ \\
\hline \multicolumn{9}{|c|}{ Model 01B: Partial mediation through self-esteem and school attachment } \\
\hline Hispanic American & $\begin{array}{r}-.47^{*} \\
(-16.54)\end{array}$ & $\begin{array}{r}.17^{*} \\
(6.25)\end{array}$ & $\begin{array}{r}-.58^{*} \\
(-20.34)\end{array}$ & $\begin{array}{r}.10^{*} \\
(4.15)\end{array}$ & $\begin{array}{r}.69^{*} \\
(17.69)\end{array}$ & $\begin{array}{c}-.02 \\
(-0.74)\end{array}$ & $\begin{array}{c}.01 \\
(.42)\end{array}$ & $\begin{array}{c}.01 \\
(.31)\end{array}$ \\
\hline European American & $\begin{array}{r}-.48^{*} \\
(-25.15)\end{array}$ & $\begin{array}{r}.10^{*} \\
(7.74)\end{array}$ & $\begin{array}{c}-.60^{*} \\
(-28.32)\end{array}$ & $\begin{array}{c}.05^{*} \\
(4.40)\end{array}$ & $\begin{array}{r}.64^{*} \\
(25.39)\end{array}$ & $\begin{array}{c}-.03^{*} \\
(-2.29)\end{array}$ & $\begin{array}{c}-.02 \\
(-1.07)\end{array}$ & $\begin{array}{r}-.03^{*} \\
(-2.25)\end{array}$ \\
\hline
\end{tabular}




\begin{tabular}{|c|c|c|c|c|c|c|c|c|}
\hline \multirow[b]{2}{*}{ Ethnic Group } & \multicolumn{2}{|c|}{$\begin{array}{c}\text { Criterion }=\text { School } \\
\text { Attachment Predictors }\end{array}$} & \multicolumn{2}{|c|}{$\begin{array}{c}\text { Criterion }= \\
\text { Self-Esteem Predictors }\end{array}$} & \multicolumn{4}{|c|}{ Criterion $=$ Depression Wave 2 Predictors } \\
\hline & $\begin{array}{l}\text { Depression } \\
\text { Wave } 1\end{array}$ & Religiousness & $\begin{array}{l}\text { Depression } \\
\text { Wave } 1\end{array}$ & Religiousness & $\begin{array}{l}\text { Depression } \\
\text { Wave } 1\end{array}$ & Religiousness & $\begin{array}{c}\text { School } \\
\text { Attachment }\end{array}$ & $\begin{array}{l}\text { Self- } \\
\text { Esteem }\end{array}$ \\
\hline \multicolumn{9}{|c|}{ Model 01B: Partial mediation through self-esteem and school attachment (continued) } \\
\hline African American & $\begin{array}{r}-.40^{*} \\
(-15.85)\end{array}$ & $\begin{array}{r}.11^{*} \\
(4.20)\end{array}$ & $\begin{array}{r}-.54^{*} \\
(-20.44)\end{array}$ & $\begin{array}{l}.13^{*} \\
(5.06)\end{array}$ & $\begin{array}{r}.60^{*} \\
(18.76)\end{array}$ & $\begin{array}{r}.08^{*} \\
(3.39)\end{array}$ & $\begin{array}{l}-.01 \\
(-.41)\end{array}$ & $\begin{array}{r}-.06^{*} \\
(-2.28)\end{array}$ \\
\hline Asian American & $\begin{array}{r}-.44^{*} \\
(-11.43)\end{array}$ & $\begin{array}{c}.07 \\
(1.77)\end{array}$ & $\begin{array}{r}-.58^{*} \\
(-16.24)\end{array}$ & $\begin{array}{c}.12^{*} \\
(3.58)\end{array}$ & $\begin{array}{r}.67^{*} \\
(13.98)\end{array}$ & $\begin{array}{l}-.01 \\
(-.38)\end{array}$ & $\begin{array}{l}.01 \\
(.15)\end{array}$ & $\begin{array}{c}-.04 \\
(-1.06)\end{array}$ \\
\hline Native American & $\begin{array}{c}-.43^{*} \\
(-8.25)\end{array}$ & $\begin{array}{c}.07 \\
(1.24)\end{array}$ & $\begin{array}{r}-.58^{*} \\
(-11.49)\end{array}$ & $\begin{array}{l}-.01 \\
(-.18)\end{array}$ & $\begin{array}{c}.53^{*} \\
(7.99)\end{array}$ & $\begin{array}{c}.06 \\
(1.43)\end{array}$ & $\begin{array}{c}-.12^{*} \\
(-2.19)\end{array}$ & $\begin{array}{l}-.02 \\
(-.27)\end{array}$ \\
\hline \multicolumn{9}{|c|}{ Model 01C: Full mediation through self-esteem and school attachment } \\
\hline Hispanic American & $\begin{array}{r}-.48^{*} \\
(-16.75)\end{array}$ & $\begin{array}{l}.12^{*} \\
(5.00)\end{array}$ & $\begin{array}{r}-.62^{*} \\
(-20.94)\end{array}$ & $\begin{array}{c}.10^{*} \\
(3.94)\end{array}$ & & & $\begin{array}{r}-.20^{*} \\
(-7.47)\end{array}$ & $\begin{array}{r}-.37^{*} \\
(-13.41)\end{array}$ \\
\hline European American & $\begin{array}{c}-.49^{*} \\
(-25.50)\end{array}$ & $\begin{array}{l}.11^{*} \\
(7.84)\end{array}$ & $\begin{array}{r}-.64^{*} \\
(-28.32)\end{array}$ & $\begin{array}{c}.05^{*} \\
(4.12)\end{array}$ & & & $\begin{array}{r}-.22^{*} \\
(-14.55)\end{array}$ & $\begin{array}{r}-.40^{*} \\
(-21.76)\end{array}$ \\
\hline African American & $\begin{array}{r}-.42^{*} \\
(-16.70)\end{array}$ & $\begin{array}{l}.11^{*} \\
(3.92)\end{array}$ & $\begin{array}{r}-.58^{*} \\
(-21.38)\end{array}$ & $\begin{array}{r}.12^{*} \\
(4.60)\end{array}$ & & & $\begin{array}{r}-.17^{*} \\
(-7.41)\end{array}$ & $\begin{array}{r}-.38^{*} \\
(-14.79)\end{array}$ \\
\hline Asian American & $\begin{array}{r}-.47^{*} \\
(-12.10)\end{array}$ & $\begin{array}{c}.07 \\
(1.67)\end{array}$ & $\begin{array}{r}-.62^{*} \\
(-16.92)\end{array}$ & $\begin{array}{l}.11^{*} \\
(3.33)\end{array}$ & & & $\begin{array}{c}-.21^{*} \\
(-5.52)\end{array}$ & $\begin{array}{r}-.41^{*} \\
(-10.76)\end{array}$ \\
\hline Native American & $\begin{array}{r}-.45^{*} \\
(-8.50)\end{array}$ & $\begin{array}{l}.02 \\
(.30)\end{array}$ & $\begin{array}{r}-.60^{*} \\
(-11.63)\end{array}$ & $\begin{array}{c}.00 \\
(-.03)\end{array}$ & & & $\begin{array}{r}-.26^{*} \\
(-4.96)\end{array}$ & $\begin{array}{r}-.32^{*} \\
(-6.03)\end{array}$ \\
\hline
\end{tabular}

Note. An empty cell denotes that parameter fixed at 0 .

*Statistically significant predictor, $p<.05$. 
was not significantly predictive of Wave 2 depression among Hispanic, Asian, and Native American adolescents.

Last, the SEM results provide some clarification regarding the means on the manifest variables. Given that Wave 1 depression was such a powerful contributor to Wave 2 depression, it would follow that ethnic groups having a lower (higher) mean depression level in Wave 1 would also have a lower (higher) mean depression level in Wave 2. European Americans who had a significantly lower mean depression level in Wave 1 than the other ethnic groups also had a significantly lower mean depression level in Wave 2 as compared to the other ethnic groups. Other differences on the manifest level could not be further clarified, given the limited effects of the other variables on depression for Hispanic, Asian, and African Americans.

Gender. Fit index estimates comparing measurement factorial invariance models for female and male participants are displayed in Table 2. Weak factorial invariance was determined to be the optimum measurement model as both the $\chi^{2} / d f$ value as well as the fit indices (e.g., RMSEA, TLI) supported weak invariance (Model 01). Weak factorial invariance constraints were then placed on the structural models and fit indices were generated (see Table 2). For gender, the partial mediation model (Model 01B) performed better than either the full or no mediation models with the lowest RMSEA and $\chi^{2} / d f$ values and highest CFI at .958 and TLI at .949 . Estimated path coefficients for the mediation models are listed in Table 4, with the best fitting partial mediation model being of most interest. Wave 1 depression exerted a significantly strong and similar direct effect on Wave 2 depression for both genders (.65). Religiousness exerted a small risk effect on Wave 2 depression for female adolescents but was not directly associated with Wave 2 depression for male adolescents. In both genders, Wave 1 depression was negatively related to self-esteem and school attachment, whereas religiousness was positively related to self-esteem and school attachment. Self-esteem was a significant mediating factor of Wave 2 depression for the male participants only. For female participants, neither self-esteem nor school attachment served as mediators. Consequently, for male adolescents there were significant indirect effects of depression and religiousness through self-esteem. The differences in effects by gender suggest that religiousness is directly associated with greater Wave 2 depression for female adolescents but is protective against Wave 2 depression for male adolescents through self-esteem.

\section{DISCUSSION}

The purpose of this study was to examine the relation between religiousness and depressive symptoms, and the potential mediating effects of self-esteem 
TABLE 4

Standardized Estimated Path Coefficients (and $t$ Values) of Structural Models for Predicting Wave 2 Depression from Wave 1 Depression, Religiousness, Self-Esteem, and School Attachment for Gender

\begin{tabular}{|c|c|c|c|c|c|c|c|c|}
\hline \multirow[b]{2}{*}{ Gender } & \multicolumn{2}{|c|}{$\begin{array}{c}\text { Criterion }=\text { School } \\
\text { Attachment Predictors }\end{array}$} & \multicolumn{2}{|c|}{$\begin{array}{c}\text { Criterion }= \\
\text { Self-Esteem Predictors }\end{array}$} & \multicolumn{4}{|c|}{ Criterion $=$ Depression Wave 2 Predictors } \\
\hline & $\begin{array}{l}\text { Depression } \\
\text { Wave } 1\end{array}$ & Religiousness & $\begin{array}{l}\text { Depression } \\
\text { Wave } 1\end{array}$ & Religiousness & $\begin{array}{l}\text { Depression } \\
\text { Wave } 1\end{array}$ & Religiousness & $\begin{array}{c}\text { School } \\
\text { Attachment }\end{array}$ & $\begin{array}{c}\text { Self- } \\
\text { Esteem }\end{array}$ \\
\hline \multicolumn{9}{|c|}{ Model 01A: No mediation through self-esteem and school attachment } \\
\hline $\begin{array}{l}\text { Male } \\
\text { Female }\end{array}$ & & & & & $\begin{array}{r}.62^{*} \\
(37.18) \\
.62^{*} \\
(39.53)\end{array}$ & $\begin{array}{c}.02 \\
(1.64) \\
.04^{*} \\
(3.11)\end{array}$ & $\begin{array}{c}-.07^{*} \\
(-5.15) \\
-.07^{*} \\
(-5.56)\end{array}$ & $\begin{array}{r}-.11^{*} \\
(-8.66) \\
-.08^{*} \\
(-7.07)\end{array}$ \\
\hline \multicolumn{9}{|c|}{ Model 01B: Partial mediation through self-esteem and school attachment } \\
\hline Female & $\begin{array}{r}-.46^{*} \\
(-28.51) \\
-.46^{*} \\
(-30.08)\end{array}$ & $\begin{array}{c}.11^{*} \\
(7.55) \\
.09^{*} \\
(6.39)\end{array}$ & $\begin{array}{c}-.54^{*} \\
(-33.73) \\
-.58^{*} \\
(-37.08)\end{array}$ & $\begin{array}{c}.10^{*} \\
(7.37) \\
.13^{*} \\
(9.78)\end{array}$ & $\begin{array}{c}.65^{*} \\
(29.79) \\
.65^{*} \\
(32.23)\end{array}$ & $\begin{array}{c}.01 \\
(0.66) \\
.03 * \\
(2.10)\end{array}$ & $\begin{array}{c}-.01 \\
(-0.54) \\
-.02 \\
(-1.59)\end{array}$ & $\begin{array}{c}-.03^{*} \\
(-2.00) \\
-.01 \\
(-0.91)\end{array}$ \\
\hline \multicolumn{9}{|c|}{ Model 01C: Full mediation through self-esteem and school attachment } \\
\hline Male & $\begin{array}{r}-.48^{*} \\
(-29.66)\end{array}$ & $\begin{array}{c}.11^{*} \\
(7.33)\end{array}$ & $\begin{array}{r}-.58^{*} \\
(-35.10)\end{array}$ & $\begin{array}{l}.10^{*} \\
(6.83)\end{array}$ & & & $\begin{array}{r}-.23^{*} \\
(-14.96)\end{array}$ & $\begin{array}{r}-.36^{*} \\
(-23.06)\end{array}$ \\
\hline Female & $\begin{array}{r}-.48^{*} \\
(-31.13)\end{array}$ & $\begin{array}{r}.09^{*} \\
(6.11)\end{array}$ & $\begin{array}{c}-.61^{*} \\
(-38.13)\end{array}$ & $\begin{array}{r}.12^{*} \\
(9.26)\end{array}$ & & & $\begin{array}{r}-.23^{*} \\
(-15.91)\end{array}$ & $\begin{array}{r}-.36^{*} \\
(-23.87)\end{array}$ \\
\hline
\end{tabular}

Note. An empty cell denotes that parameter fixed at 0

${ }^{*}$ Statistically significant predictor, $p<.05$. 
and school attachment, for male and female adolescents in five different ethnic groups. We failed to find support for a mediating role of school attachment in the link between religiousness and depression. It would seem that any observed effects of religiousness on depression do not necessarily operate through school-related attitudes. However, religiousness was a significant predictor of depression for European American and African American adolescents. Specifically, for European Americans, religiousness played a modest protective role directly, and indirectly through self-esteem. Hence, religiousness was negatively related to depression and positively related to self-esteem, which in turn negatively influenced depression. This finding is consistent with extant research that suggests more religious involvement is associated with less depressive symptoms in adolescents (e.g., Schapman \& Inderbitzen-Nolan, 2002).

For African Americans, the protective role of religiousness through selfesteem was negated by the direct positive relation between religiousness and depression. The negative relation between religiousness and depression through self-esteem can be explained by the cultural value hypothesis, which suggests that an increase in self-esteem results from religious involvement because one is engaging in culturally valued behavior (C. B. Smith et al., 1979). African American adolescents in our study had higher manifest levels of self-esteem than any of the other ethnic groups. The high self-esteem of African Americans has been attributed to a stronger sense of community and a proud, steadfast ethnic identity (Ward, 2002), which may be bolstered by the important role that religion occupies in their lives. Consistent with past research (Donahue \& Benson, 1995; Eliassen et al., 2005; Markstrom, 1999), African Americans also reported the highest levels of religiousness in this study. Given the important role that religion occupies in the lives of African Americans, these adolescents may feel good about themselves because they are engaging in the culturally valued behavior of religious participation, behavior that enhances their ethnic identity. Nevertheless, the positive relation between religiousness and depression was unexpected. One possibility is that different aspects of religiousness can affect well-being in different ways (we elaborate on this point later on).

Alternatively, there may be third variables associated with both religiousness and depression that have not been accounted for such as experiences associated with ethnic minority status. Indeed, consistent with past research (Rushton, Forcier, \& Schectman, 2002; Schraedley, Gotlib, \& Hayward, 1999), adolescents in each of the ethnic minority groups in our study had higher levels of depression than European American adolescents. For African American adolescents, their ethnic identity is linked both to religiousness as well as a history of enduring racial discrimination. A recent U.S. Surgeon General's Report (Office of the Surgeon General, 1999) suggested that the higher levels of depression in minority youth are related to perceived discrimination and experiences with racism, which lead to increased stress and psychological distress. Negative racial stereotypes 
and images may be internalized by minorities, jeopardizing their well-being. In addition, discrimination plays a role in minorities' lower socioeconomic status, educational attainment, and occupational status, as well as their poorer living conditions, all of which are related to increased stress and poorer mental health (Office of the Surgeon General, 1999). Given that minority youth may be starting from a position of disadvantage in terms of higher depression rates due to their contextual circumstances, more research attention should be given to the processes underlying depression for these ethnic groups and the factors that may serve to protect their mental well-being.

It is important to note that, contrary to expectations, religiousness was not a predictor of depression for Hispanic, Asian, or Native Americans. A possible explanation is that there may be more pronounced within-group variation in the relation between religiousness and depression. All three groups are quite heterogeneous; therefore, the relation between religiousness and depression may vary within the particular subgroups that make up these broad racial categories. Future research should investigate ethnicity at a more refined level of analysis to further understanding about the relation between religiousness and adolescent depression.

Finally, consistent with past research, female adolescents had higher levels of religiousness (Donahue \& Benson, 1995; Eliassen et al., 2005; Wright et al., 1993) and depression (Eliassen et al., 2005: Pearce et al., 2003; Portes \& Zady, 2002; Roberts \& Gamble, 2001; Wright et al., 1993) and lower levels of selfesteem (Roberts \& Gamble, 2001) on the manifest scales. However, religiousness was unexpectedly related to increased depression for female adolescents. For male adolescents, self-esteem, which was negatively related to Wave 1 depression and positively related to religiousness, served as a protective factor. These results suggest that male adolescents' initial higher levels of self-esteem and lower levels of depression, as compared to female adolescents, are particularly protective for them. The gender discrepancy in adolescents' self-esteem and depression has been attributed to differential gender socialization. Female adolescents are encouraged to develop and express nurturing, feminine behaviors, which are grounded in submission, dependence, frailty, and helplessness (Ornstein, 1995). In addition, the emphasis for female adolescents is on their body and appearance, which can be stressful for developing adolescents who are trying to attain an unrealistic cultural ideal (Hankin \& Abramson, 1999). Male adolescents, on the other hand, are encouraged to express independence and self-reliance and are given opportunities in which they can develop real competencies and talents (Ornstein, 1995). As a result, differential socialization may make adolescence a more stressful time for female adolescents, resulting in lower self-esteem and higher depression. Whether or not religious socialization affects male and female adolescents differentially is a topic worth pursuing in future research. 
Despite the importance of the conclusions of this study, a few limitations should be considered when interpreting the findings. One limitation is that the analysis did not account for other factors, such as adolescents' age, socioeconomic status, family structure, and closeness or attachment to parent, which may confound or mediate the relation among religiousness, depression, school attachment, and self-esteem. However, given the paucity of research in the area of adolescent religiousness and depression, this study has taken the first step in integrating existing strands of related research.

Another limitation concerns the diversity within the Hispanic, Asian, and Native American groups. There is variation within these ethnic groups that was not assessed in our analyses. It is possible that the variables studied play distinctively different roles for adolescents when these broad ethnic categories are more finely distinguished. Similarly, our gender analyses combined all ethnic groups. Investigating gender differences separately for each ethnic group would strengthen future studies.

A third limitation is that the data were gathered through self-report scales. As a result, it is difficult to be confident that adolescents' responses represent their true attitudes and behaviors rather than what they perceive to be as more socially acceptable responses. For example, they may want to appear more religious than they are or they may indicate more positive attachment to their schools than they actually feel. However, given that the data are from a large, nationally representative sample of adolescents, we believe this limitation is reduced. Further research, though, is needed in which several methods of assessment, such as diaries or observations, are used to obtain information about adolescents' attitudes and behaviors.

A fourth limitation is the operationalization of the religiousness variable. In this study, religiousness was an aggregate of four items: two each of internal and external dimensions of religiousness. Specifically, religiousness captured the importance of religion and frequency of prayer, religious service attendance, and religious-related youth activities. As such, the religiousness variable was more of a global measure, representing various aspects of religious experience. It can be argued that using a global measure is advantageous because it more accurately represents people's real religious experiences, which often include various practices and beliefs. However, this approach also can be limiting, because using an aggregated measure may mask a relation between religiousness and depression that would be detected had the various dimensions of religiousness been measured separately. For example, it may be that the importance of religion is a protective factor for depression but that frequency of prayer is not. Furthermore, religiousness may mean different things to different ethnic groups. Other aspects of religious involvement may also be important such as negative interpersonal experience with one's religious group which has been associated with greater depression (Pearce et al., 2003; Rook, 1998). Therefore, the construct validity 
of our religiousness variable is questionable and may account for the lack of significant findings between religiousness and depression for Asian, Hispanic, and Native American adolescents. We are not aware of any research in which the construct of religiousness as it differs across ethnic groups has been investigated. This is an area ripe for research, as is developing ethnically or culturally relevant measures of religiousness.

Relatedly, our religiousness variable in this study taps into Judeo-Christian aspects of religious practice in which prayer and attendance of religious services are common aspects of religious experience. It is possible that religiousness, as operationalized in this study, has limited applicability to religiousness as experienced by adolescents in non-Judeo-Christian religions and/or those who are spiritual but do not practice a religion.

Finally, although the sample for this study is a national representation of adolescents in the United States, the generalizability of the findings are limited to school-based adolescents. Inferences should not be made to adolescents who are not enrolled in school.

Despite these limitations, this study provides important information about the relation among religiousness, depression, self-esteem, and school attachment for male and female adolescents from five different ethnic groups. The findings from this study add to the limited research on the subject of religiousness and depression in adolescence. By using longitudinal data with a nationally representative sample of adolescents from five different ethnic groups and by including variables that potentially mediate the relation between religion and depression, the findings from this study fill important gaps in the research, add to our understanding of the relation between religiousness and depression, and suggest some directions for further research aimed at understanding adolescent well-being.

\section{ACKNOWLEDGMENTS}

We are grateful to Gary Stockdale and Judy Wallen for providing statistical support.

\section{REFERENCES}

Abbotts, J. E., Williams, R. G. A., Sweeting, H. N., \& West, P. B. (2004). Is going to church good or bad for you? Denomination, attendance and mental health of children in West Scotland. Social Science \& Medicine, 58, 645-656.

Anderman, E. M. (2002). School effects on psychological outcomes during adolescents. Journal of Educational Psychology, 94, 795-809.

Baetz, M., Griffin, R., Bowen, R., Koenig, H. G., \& Marcoux, E. (2004). The association between spiritual and religious involvement and depressive symptoms in a Canadian population. Journal of Nervous and Mental Disease, 192, 818-822. 
Bagley, C., \& Mallick, K. (1997). Self-esteem and religiosity: Comparison of 13- to 15-yearold students in Catholic and public junior high schools. Canadian Journal of Education, 22, 89-92.

Bahr, H. M., \& Martin, T. K. (1983). "And thy neighbor as thyself”: Self-esteem and faith in people as correlates of religiosity and family solidarity among Middletown high school students. Journal for the Scientific Study of Religion, 22, 132-144.

Ball, J., Armistead, L., \& Austin, B. (2003). The relationship between religiosity and adjustment among African-American, female, urban adolescents. Journal of Adolescence, 26, 431-446.

Benson, P. L., Donahue, M. J., \& Erickson, J. A. (1989). Adolescents and religion: A review of the literature from 1970-1986. Research in the Social Scientific Study of Religion, 1, 153-181.

Birmaher, B., Ryan, N., Williamson, D., Brent, D., Kaufman, J., Dahl, R., et al. (1996). Childhood and adolescent depression: A review of the past 10 years. Part I. Journal of the American Academy of Child \& Adolescent Psychiatry, 35, 1427-1439.

Cheng, H., \& Furnham, A. (2003). Personality, self-esteem, and demographic predictions of happiness and depression. Personality and Individual Differences, 34, 921-942.

Donahue, M. J., \& Benson, P. L. (1995). Religion and the well-being of adolescents. Journal of Social Issues, 51, 145-160.

Eliassen, A. H., Taylor, J., \& Lloyd, D. A. (2005). Subjective religiosity and depression in the transition to adulthood. Journal for the Scientific Study of Religion, 44, 187-199.

Francis, L. J. (1992). The influence of religion, gender, and social class on attitudes toward school among 11-year-olds in England. Journal of Experimental Education, 60, 339-348.

Greening, L., \& Stoppelbein, L. (2002). Religiosity, attributional style, and social support as psychosocial buffers for African American and White adolescents' perceived risk for suicide. Suicide \& Life-Threatening Behavior, 32, 404-417.

Hackney, C. H., \& Sanders, G. S. (2003). Religiosity and mental health: A meta-analysis of recent studies. Journal for the Scientific Study of Religion, 42, 43-55.

Hankin, B. L., \& Abramson, L. Y. (1999). Development of gender differences in depression: Description and possible explanations. Annals of Medicine, 31, 372-379.

Hunsberger, B., Pratt, M., \& Pancer, S. M. (2001). Religious versus nonreligious socialization: Does religious background have implications for adjustment? International Journal for the Psychology of Religion, 11, 105-128.

Kishton, J. M., \& Widaman, K. F. (1994). Unidimensional versus domain representative parceling of questionnaire items: An empirical example. Educational and Psychological Measurement, 54, $757-765$.

Koenig, H. G. (2001). Religion and medicine II: Religion, mental health, and related behaviors. International Journal of Psychiatry in Medicine, 31(1), 97-109.

Markstrom, C. A. (1999). Religious involvement and adolescent psychosocial development. Journal of Adolescence, 22, 205-221.

Miller, L., \& Gur, M. (2002). Religiosity, depression, and physical maturation in adolescent girls. Journal of the American Academy of Child and Adolescent Psychiatry, 41, 206-214.

Mizell, C. A. (1999). African American men's personal sense of mastery: The consequences of adolescent environment, self-concept, and adult achievement. Journal of Black Psychology, 25, 210-230

Mouton, S. G., Hawkins, J., McPherson, R. H., \& Copley, J. (1996). School attachment: Perspectives of low-attached high school students. Educational Psychology, 16, 297-304.

Muthén, L. K., \& Muthén, B. O. (2003). Mplus: The comprehensive modeling program for applied researchers. User's guide. Los Angeles, CA: Author.

Office of the Surgeon General. (1999). Mental health: Culture, race, and ethnicity: A supplement to mental health: A report of the Surgeon General. Washington, DC: U.S. Department of Health and Human Services, Office of the Surgeon General, SAMHSA. 
Office of the Surgeon General. (2001). Mental health: Culture, race, and ethnicity: A supplement to mental health: A report of the Surgeon General. Washington, DC: U.S. Department of Health and Human Services, Office of the Surgeon General, SAMHSA.

Ornstein, P. (1995). Schoolgirls: Young women, self-esteem and the confidence gap. New York: Anchor.

Pearce, M. J., Little, T. D., \& Perez, J. E. (2003). Religiousness and depressive symptoms among adolescents. Journal of Clinical Child and Adolescent Psychology, 32, 267-276.

Peltzer, K. (2005). Religiosity, personal distress and minor psychiatric morbidity among Black students in South Africa. Social Behavior and Personality, 33, 723-734.

Portes, P. R., \& Zady, M. (2002). Self-esteem in the adaptation of Spanish-speaking adolescents: The role of immigration, family conflict, and depression. Hispanic Journal of Behavioral Sciences, 24, 296-318.

Radloff, L. S. (1977). The CES-D Scale: A self-report depression scale for research in the general population. Applied Psychological Measurement 1, 385-401.

Roberts, J. E., \& Gamble, S. A. (2001). Current mood-state and past depression as predictors of selfesteem and dysfunctional attitudes among adolescents. Personality and Individual Differences, 30, 1023-1037.

Robertson, J. F., \& Simons, R. L. (1989). Family factors, self-esteem, and adolescent depression. Journal of Marriage and the Family, 51, 125-138.

Rook, K. S. (1998). Investigating the positive and negative sides of personal relationships: Through a lens darkly? In B. H. Spitzberg \& W. R. Cupach (Eds.), The dark side of close relationships (pp. 369-393). Mahwah, NJ: Lawrence Erlbaum Associates.

Rosenberg, M. R. (1965). Society and adolescent self-image. Princeton, NJ: Princeton University.

Rushton, J. L., Forcier, M., \& Schectman, R. M. (2002). Epidemiology of depressive symptoms in the National Longitudinal Study of Adolescent Health. Journal of the American Academy of Child and Adolescent Psychiatry, 41, 199-205.

Schapman, A. M., \& Inderbitzen-Nolan, H. M. (2002). The role of religious behaviour in adolescent depressive and anxious symptomatology. Journal of Adolescence, 25, 631-643.

Schraedley, P. K., Gotlib, I. H., \& Hayward, C. (1999). Gender differences in correlates of depressive symptoms in adolescence. Journal of Youth and Adolescence, 25, 98-108.

Smith, C. B., Weigert, A. J., \& Thomas, D. L. (1979). Self-esteem and religiosity: An analysis of Catholic adolescents from five cultures. Journal for the Scientific Study of Religion, 18, 51-60.

Smith, T. B., McCullough, M. E., \& Poll, J. (2003). Religiousness and depression: Evidence for a main effect and the moderating influence of stressful life events. Psychological Bulletin, 129, 614-636.

Ward, J. V. (2002). The skin we're in: Teaching our teens to be emotionally strong, socially smart, and spiritually connected. New York: Free Press.

Wright, L. S., Frost, C. J., \& Wisecarver, S. J. (1993). Church attendance, meaningfulness of religion, and depressive symptomatology among adolescents. Journal of Youth and Adolescence, $22,559-568$. 


\section{APPENDIX}

TABLE A1

Intercorrelations Among Manifest Scales for Ethnic Groups

\begin{tabular}{|c|c|c|c|c|c|}
\hline & $D E 1$ & $D E 2$ & $S E$ & $S A$ & $R E$ \\
\hline \multicolumn{6}{|l|}{ Hispanic American ${ }^{\mathrm{a}}$} \\
\hline Depression Wave 1 & 1.00 & & & & \\
\hline Depression Wave 2 & $.55^{*}$ & 1.00 & & & \\
\hline Self-esteem & $-.47^{*}$ & $-.32 *$ & 1.00 & & \\
\hline School attachment & $-.31^{*}$ & $-.20^{*}$ & $.37^{*}$ & 1.00 & \\
\hline Religiousness & $-.10^{*}$ & $-.13^{*}$ & $.09^{*}$ & $.17^{*}$ & 1.00 \\
\hline \multicolumn{6}{|l|}{ European American ${ }^{\mathrm{b}}$} \\
\hline Depression Wave 1 & 1.00 & & & & \\
\hline Depression Wave 2 & $.60^{*}$ & 1.00 & & & \\
\hline Self-esteem & $-.55^{*}$ & $-.41^{*}$ & 1.00 & & \\
\hline School attachment & $-.41^{*}$ & $-.31^{*}$ & $.42^{*}$ & 1.00 & \\
\hline Religiousness & $-.10^{*}$ & $-.11^{*}$ & $.12^{*}$ & $.16^{*}$ & 1.00 \\
\hline \multicolumn{6}{|l|}{ African American ${ }^{c}$} \\
\hline Depression Wave 1 & 1.00 & & & & \\
\hline Depression Wave 2 & $.48^{*}$ & 1.00 & & & \\
\hline Self-esteem & $-.44^{*}$ & $-.33^{*}$ & 1.00 & & \\
\hline School attachment & $-.30^{*}$ & $-.20^{*}$ & $.31^{*}$ & 1.00 & \\
\hline Religiousness & $-.07 *$ & $-.10^{*}$ & $.08^{*}$ & $.10^{*}$ & 1.00 \\
\hline \multicolumn{6}{|l|}{ Asian American ${ }^{\mathrm{d}}$} \\
\hline Depression Wave 1 & 1.00 & & & & \\
\hline Depression Wave 2 & $.60^{*}$ & 1.00 & & & \\
\hline Self-esteem & $-.50 *$ & $-.36^{*}$ & 1.00 & & \\
\hline School attachment & $-.35^{*}$ & $-.18^{*}$ & $.37^{*}$ & 1.00 & \\
\hline Religiousness & $.00^{*}$ & $.05^{*}$ & $.11^{*}$ & $.08^{*}$ & 1.00 \\
\hline \multicolumn{6}{|l|}{ Native American ${ }^{\mathrm{e}}$} \\
\hline Depression Wave 1 & 1.00 & & & & \\
\hline Depression Wave 2 & $.59^{*}$ & 1.00 & & & \\
\hline Self-esteem & $-.52 *$ & $-.34^{*}$ & 1.00 & & \\
\hline School attachment & $-.36^{*}$ & $-.26^{*}$ & $.30^{*}$ & 1.00 & \\
\hline Religiousness & -.03 & $-.14^{*}$ & -.03 & .00 & 1.00 \\
\hline
\end{tabular}

Note. $\mathrm{DE} 1=$ Depression Wave $1 ; \mathrm{DE} 2=$ Depression Wave $2 ; \mathrm{SE}=$ self-esteem; $\mathrm{SA}=$ school attachment; $\mathrm{RE}=$ religiousness.

${ }^{\mathrm{a}} n=2,033 .{ }^{\mathrm{b}} n=6,929 .{ }^{\mathrm{c}} n=2,706 .{ }^{\mathrm{d}} n=981 .{ }^{\mathrm{e}} n=459$.

${ }^{*} p<.05$. 
TABLE A2

Intercorrelations Among Manifest Scales for Gender

\begin{tabular}{|c|c|c|c|c|c|}
\hline & $D E 1$ & $D E 2$ & $S E$ & $S A$ & $R E$ \\
\hline \multicolumn{6}{|l|}{ Female $^{\mathrm{a}}$} \\
\hline Depression Wave 1 & 1.00 & & & & \\
\hline Depression Wave 2 & $.63^{*}$ & 1.00 & & & \\
\hline Self-esteem & $-.46^{*}$ & $-.34^{*}$ & 1.00 & & \\
\hline School attachment & $-.38^{*}$ & $-.29^{*}$ & $.34^{*}$ & 1.00 & \\
\hline Religiousness & $-.09^{*}$ & $-.08^{*}$ & $.14^{*}$ & $.12^{*}$ & \\
\hline \multicolumn{6}{|l|}{ Male $^{\mathrm{b}}$} \\
\hline Depression Wave 1 & 1.00 & & & & \\
\hline Depression Wave 2 & $.62^{*}$ & 1.00 & & & \\
\hline Self-esteem & $-.41^{*}$ & $-.32 *$ & 1.00 & & \\
\hline School attachment & $-.35^{*}$ & $-.27 *$ & $.33^{*}$ & 1.00 & \\
\hline Religiousness & $-.05^{*}$ & $-.06^{*}$ & $.09^{*}$ & $.11^{*}$ & 1.00 \\
\hline
\end{tabular}

Note. $\mathrm{DE} 1=$ Depression Wave $1 ; \mathrm{DE} 2=$ Depression Wave $2 ; \mathrm{SE}=$ self-esteem; $\mathrm{SA}=$ school attachment; $\mathrm{RE}=$ religiousness.

${ }^{\mathrm{a}} n=6,813 .{ }^{\mathrm{b}} n=6,504$.

${ }^{*} p<.05$. 
Copyright of International Journal for the Psychology of Religion is the property of Lawrence Erlbaum Associates and its content may not be copied or emailed to multiple sites or posted to a listserv without the copyright holder's express written permission. However, users may print, download, or email articles for individual use. 